\title{
Effects of Supplemental Calcium Carbonate on the Metab- olism of Iron, Copper, Zinc and Manganese in Sheep
}

\author{
Hideo Yano, Masaru NoKata* and Ryoji Kawashima \\ Department of Animal Science, College of Agriculture, Kyoto \\ University, Kyoto-shi 606
}

(Received March 1, 1978)

\begin{abstract}
Nine sheep were divided into three groups, three sheep in each. Each group was given a ration containing respectively $0.1,0.6$ and $1.2 \%$ calcium. The dietary calcium level was adjusted by the addition of calcium carbonate. From the 30th and the 60th day after the beginning of trial, urine, fecal and serum samples were taken for seven days. After a 67-days feeding period, two sheep from each group were sacrificed, and the livers and spleens were examined to determine trace mineral concentrations. The amount of all trace minerals excreted via urine were too little to affect the mineral balances. There was no significant difference in serum mineral concentrations among treatment groups. Fecal excretion of iron and copper significantly increased and retentions of these trace minerals became negative when the highest calcium ration was given. Liver iron and copper concentrations did not consistently alter, but spleen iron and copper showed a decreasing trend as the dietary calcium was increased. It may be possible that iron and copper requirements increase when a high level of calcium carbonate is given to cattle and sheep.
\end{abstract}

In recent years wheat bran and rice bran, which are rich in phosphorus, have been frequently used for fattening cattle and simultaneously calcium carbonate is added to rations in order to adjust a dietary ratio of calcium to phosphorus. It has been shown in sheep that liver-iron ${ }^{11}$ or liver-copper stores ${ }^{2}$ decreased when dietary calcium was elevated. UNDERWOOD ${ }^{3)}$ described that, in cattle, the availability of copper lowered when there was an increase in the dietary calcium content. It was also reported in monogastric animals that a high calcium ration decreased zinc absorption in the intestine ${ }^{4-\tau)}$ or induced manganese deficiency ${ }^{8}$.

However, it seems that only a little consideration has been paid to the availability of trace minerals when a high level of calcium carbonate is given to cattle and sheep. This experiment was conducted to study the influence of high dietary calcium ration on the metabolism of iron, copper, zinc and manganese in sheep.

\section{Materials and Methods}

Nine corriedale wethers averaging $42 \mathrm{~kg}$ were divided, on a weight basis, into three groups, three sheep in each. Each group was given a ration containing respectively 0.1, 0.6 and $1.2 \%$ calcium. The dietary calcium level was adjusted by the addition of calcium carbonate and mineral

* Present address: Laboratory of Nihon Noyaku Co., Kawachinagano-shi 586

Jap. J. Zootech. Sci., 49, (8):625-631.

1978. 8. 
Yano, Nokata and Kawashima

Table 1. Composition of basal ration and its mineral concentrations.

(air dry matter basis)

\begin{tabular}{|c|c|c|c|c|c|}
\hline Barley & $56 \%$ & Calcium & $0.10 \%$ & Iron & $409 \mu \mathrm{g} / \mathrm{g}$ \\
\hline \multirow{2}{*}{ Wheat bran } & \multirow[b]{2}{*}{24} & \multirow{2}{*}{ Phosphorus } & \multirow{2}{*}{0.53} & Copper & 6 \\
\hline & & & & Zinc & 54 \\
\hline Rice straw & 20 & Magnesium & 0.22 & Manganese & 142 \\
\hline
\end{tabular}

contents of the basal ration are shown in Table 1. Chopped rice straw was given as a roughage source.

Sheep were placed in metabolism cages throughout the experimental period. The ration was given twice a day at the level of $1 \%$ of the body weight. Water was available at all times. From the 30th and the 60th day after the beginning of trial, urine, fecal and serum samples were taken for seven days. Urine and fecal samples were taken everyday from 24-hour collections during the sampling period. Serum samples were obtained twice in the same period.

After the feeding period, two sheep from each group were sacrificed, and samples of liver and spleen were taken to determine the concentrations of iron, copper, zinc and manganese.

Analytical samples for urine, feces, rations and organs were prepared by ashing with nitric acid and perchloric acid. That is, $15 \mathrm{ml}$ of nitric acid solution and $10 \mathrm{ml}$ of perchloric acid solution were used for ashing a sample. After the process of ashing, mineral components were extracted by $5 \mathrm{~m} l$ of hydrochloric acid solution $\left(\mathrm{HCl} / \mathrm{H}_{2} \mathrm{O} ; 1 / 1\right)$ and $20 \mathrm{~m} l$ of purified water. Trace mineral concentrations in these samples were analyzed by an atomic absorption spectrophotometry. Dietary phosphorus concentrations were determined by the method of FisKe-SubBarow ${ }^{99}$.

A serum sample of $3 \mathrm{~m} l$ was mixed with $1.5 \mathrm{~m} l$ of $1 \mathrm{~N}$ hydrochloric acid solution, and then the sample was boiled for 5 minutes. After being added by $1.5 \mathrm{~m} l$ of $10 \%$ trichloric acid solution, the serum sample was centrifuged at $3000 \mathrm{rpm}$ for 10 minutes. The supernatant was analyzed for trace mineral concentrations.

\section{Results}

Table 2 shows the amount of urine excretion of trace minerals. There was no obvious difference in urine excretion of trace minerals among three rations. In the urine excretion at the percentage basis, all trace minerals examined in this experiment were under $1.0 \%$. When compared with iron, copper and zinc, the percentage of dietary manganese excreted in urine appeared to be less.

Fecal excretion of iron significantly increased when the highest calcium ration was fed $(\mathrm{P}<.05)$. Although no great difference was observed among three rations at one month after the beginning of trial, the amount of copper excretion via feces was larger in the highest calcium ration than that in the lowest calcium ration at two months after $(\mathrm{P}<.05)$. Fecal manganese excretion in the ration containing $0.6 \%$ calcium appeared to be lower than those in the other two rations. Fecal zinc excretion also slightly decreased when the ration containing $0.6 \%$ calcium was given.

As shown in Table 4, iron and copper retentions became lower with the increasing of dietary calcium. And significant differences were found in these mineral retentions between the lowest and the highest calcium rations $(\mathrm{P}<.05)$. Retentions of zinc and manganese showed no obvious tendency though a little increase was found in manganese in the ration of $0.6 \%$ calcium. 
Adding $\mathrm{CaCo}_{3}$ on Trace Mineral Metabolism

Table 2. Effects of supplemental calcium carbonate on urine excretion of iron, copper, zinc and manganese.

\begin{tabular}{|c|c|c|c|c|c|c|}
\hline & \multicolumn{6}{|c|}{ Dietary calcium, (\%) } \\
\hline & \multicolumn{3}{|c|}{1 month after } & \multicolumn{3}{|c|}{2 months after } \\
\hline & 0.1 & 0.6 & 1.2 & 0.1 & 0.6 & 1.2 \\
\hline \multicolumn{7}{|c|}{ Urine excretion, mg/day } \\
\hline Iron & 0.41 & 0.25 & 0.52 & 0.41 & 0.36 & 0.44 \\
\hline Copper & 0.04 & 0.03 & 0.05 & 0.04 & 0.04 & 0.04 \\
\hline Zinc & 0.20 & 0.19 & 0.22 & 0.26 & 0.29 & 0.19 \\
\hline Manganese & 0.05 & 0.04 & 0.06 & 0.07 & 0.08 & 0.08 \\
\hline \multicolumn{7}{|c|}{$\%$ of dietary intake excreted in urine } \\
\hline Iron & 0.12 & 0.07 & 0.15 & 0.12 & 0.11 & 0.13 \\
\hline Copper & 0.83 & 0.65 & 0.98 & 0.80 & 0.88 & 0.80 \\
\hline Zinc & 0.41 & 0.45 & 0.47 & 0.56 & 0.69 & 0.41 \\
\hline Manganese & 0.04 & 0.04 & 0.05 & 0.06 & 0.07 & 0.07 \\
\hline
\end{tabular}

Table 3. Effects of supplemetal calcium carbonate on fecal excretion of iron, copper, zinc and manganese.

\begin{tabular}{|c|c|c|c|c|c|c|}
\hline & \multicolumn{6}{|c|}{ Dietary calcium, (\%) } \\
\hline & \multicolumn{3}{|c|}{1 month after } & \multicolumn{3}{|c|}{2 months after } \\
\hline & 0.1 & 0.6 & 1.2 & 0.1 & 0.6 & 1.2 \\
\hline \multicolumn{7}{|c|}{ Fecal excretion, mg/day } \\
\hline Iron & $324^{\mathrm{a}}$ & $346^{\mathrm{a}}$ & $488^{\mathrm{b}}$ & $295^{\mathrm{a}}$ & $254^{\mathrm{a}}$ & $431^{\circ}$ \\
\hline S. D. & \pm 47 & \pm 58 & \pm 87 & \pm 58 & \pm 54 & \pm 89 \\
\hline Copper & 4.7 & 5.3 & 5.3 & 4. $7^{\mathrm{a}}$ & $5.0^{\mathrm{ab}}$ & $6.3^{\mathrm{b}}$ \\
\hline S. D. & \pm 1.0 & \pm 1.1 & \pm 1.3 & \pm 0.9 & \pm 1.7 & \pm 1.3 \\
\hline Zinc & 44 & 36 & 43 & 43 & 38 & 45 \\
\hline S. D. & \pm 4 & \pm 7 & \pm 10 & \pm 6 & \pm 5 & \pm 11 \\
\hline Manganese & 102 & 82 & 110 & $106^{\mathrm{a}}$ & $81^{b}$ & $99^{\mathrm{ab}}$ \\
\hline S. D. & \pm 21 & \pm 7 & \pm 43 & \pm 6 & \pm 7 & \pm 16 \\
\hline
\end{tabular}

$a$ and $b$ : Means with different superscript letters differ significantly $(P<.05)$.

Table 5 shows serum concentrations of iron, copper and zinc. Among the three rations, no significant difference was found in serum concentrations of iron, copper and zinc. Serum iron and copper tended to be a little higher in sheep given $0.6 \%$ calcium ration than in animals given the other rations. Serum manganese concentrations were too low to be determined by the method used in this experiment.

The results of trace mineral concentrations in livers and spleens are presented in Table 6. Liver iron and copper had large individual variations and showed no consistent tendency when dietary calcium levels were changed. Though large variations were also found, spleen iron and copper showed a trend to decrease with an increase in the dietary calcium concentration. Spleen 
Table 4. Effects of supplemetal calcium carbonate on retentions of iron, copper, zinc and manganese.

\begin{tabular}{|c|c|c|c|c|c|c|}
\hline & \multicolumn{6}{|c|}{ Dietary calcium, (\%) } \\
\hline & \multicolumn{3}{|c|}{1 month after } & \multicolumn{3}{|c|}{2 months after } \\
\hline & 0.1 & 0.6 & 1.2 & 0.1 & 0.6 & 1.2 \\
\hline \multicolumn{7}{|c|}{ Retention, mg/day } \\
\hline Iron & $15^{\mathrm{a}}$ & $-23^{\mathrm{ab}}$ & $-136^{b}$ & $55^{\mathrm{a}}$ & $63^{a}$ & $-86^{b}$ \\
\hline Copper & 0.1 & -0.7 & -0.2 & $0.3^{\mathrm{a}}$ & $-0.5^{\mathrm{ab}}$ & $-1.3^{b}$ \\
\hline Zinc & 1.1 & 6.2 & 4.5 & 3.7 & 3.6 & 1.3 \\
\hline Manganese & 15.9 & 29.9 & 13.4 & 15.6 & 29.0 & 22.0 \\
\hline \multicolumn{7}{|l|}{$\%$ of intake } \\
\hline Iron & $4^{\mathrm{a}}$ & $-8^{a}$ & $-39^{\mathrm{b}}$ & $16^{\mathrm{a}}$ & $19^{a}$ & $-25^{b}$ \\
\hline Copper & 2 & -15 & -4 & $7^{\mathrm{a}}$ & $-11^{a b}$ & $-26^{b}$ \\
\hline Zinc & 2 & 14 & 10 & 8 & 8 & 3 \\
\hline Manganese & 14 & 27 & 11 & 13 & 26 & 18 \\
\hline
\end{tabular}

$a$ and $b$ : Means with different superscript letters differ significantly $(P<.05)$.

Table 5. Effects of supplemental calcium carbonate on serum concentrations of iron, copper and zinc.

\begin{tabular}{|c|c|c|c|c|c|c|}
\hline & \multicolumn{6}{|c|}{ Dietary calcium, (\%) } \\
\hline & \multicolumn{3}{|c|}{1 month after } & \multicolumn{3}{|c|}{2 months after } \\
\hline & 0.1 & 0.6 & 1.2 & 0.1 & 0.6 & 1.2 \\
\hline \multicolumn{7}{|c|}{ Serum values, $\mu \mathrm{g} / \mathrm{m} l$} \\
\hline Iron & 2.89 & 2.99 & 2.57 & 2.57 & 3.28 & 2.37 \\
\hline S.D. & \pm 0.74 & \pm 0.86 & \pm 0.65 & \pm 0.61 & \pm 0.50 & \pm 0.16 \\
\hline Copper & 0.67 & 0.94 & 0.83 & 0.72 & 1.05 & 0.85 \\
\hline S.D. & \pm 0.06 & \pm 0.28 & \pm 0.19 & \pm 0.13 & \pm 0.30 & \pm 0.18 \\
\hline Zinc & 0.59 & 0.65 & 0.62 & 0.70 & 0.68 & 0.68 \\
\hline S. D. & \pm 0.02 & \pm 0.10 & \pm 0.05 & \pm 0.05 & \pm 0.03 & \pm 0.01 \\
\hline
\end{tabular}

iron concentrations in the highest calcium ration were about a half of those in the lowest calcium ration. No obvious difference was found in zinc and manganese concentrations of the livers and spleens among three rations.

\section{Discussion}

In the percentage of the dietary intake excreted via urine, all trace minerals were under $1.0 \%$. Therefore, the amount of urine excretion of trace minerals was too little to affect the retetions. It is described in nonruminants and ruminants that high percentage of iron ${ }^{10)}$, copper ${ }^{11-13)}$, $z_{\text {zinc }}{ }^{14-16)}$ and manganese ${ }^{17-18)}$ excreted from the body are mainly through feces and very little by way of urine. 
Adding $\mathrm{CaCo}_{3}$ on Trace Mineral Metabolism

Table 6. Effects of supplemetal calcium carbonate on iron, copper, zinc and manganese concentrations of liver and spleen. ( $\mu \mathrm{g} / \mathrm{g}$, dry matter basis)

\begin{tabular}{|c|c|c|c|c|c|c|c|c|}
\hline & & \multirow[b]{3}{*}{ Sheep No. } & \multicolumn{6}{|c|}{ Dietary calcium, (\%) } \\
\hline & & & \multicolumn{2}{|c|}{0.1} & \multicolumn{2}{|c|}{0.6} & \multicolumn{2}{|c|}{1.2} \\
\hline & & & 1 & 2 & 3 & 4 & 5 & 6 \\
\hline \multicolumn{9}{|c|}{ Iron } \\
\hline & Liver & & 75 & 105 & 100 & 63 & 94 & 81 \\
\hline & Spleen & & 2760 & 1275 & 1530 & 236 & 535 & 750 \\
\hline \multicolumn{9}{|c|}{ Copper } \\
\hline & Liver & & 788 & 2.62 & 309 & 688 & 180 & 803 \\
\hline & Spleen & & 2.3 & 1.8 & 2.1 & 2.1 & 1,4 & 1.3 \\
\hline \multirow[t]{6}{*}{ : } & Zinc & & & & & & & \\
\hline & Liver & & 109 & 81 & 69 & 79 & 69 & 119 \\
\hline & Spleen & & 112 & 119 & 76 & 96 & 68 & 10,1 \\
\hline & Manganes & & & & & & & \\
\hline & Liver & & 5.0 & 7.3 & 5.6 & 5.9 & 7.0 & 5.8 \\
\hline & Spleen & & 3.1 & 3.0 & 3.1 & - & 2.9 & 3.4 \\
\hline
\end{tabular}

In this experiment, fecel iron excretion became higher, and iron retentions and spleen iron concentrations became lower with the elevation of dietary calcium. It is conceivable from these results that the amount of iron requirement is increased when a high calcium ration is given to ruminants. However, liver iron concentrations were not affected by the administration of calcium carbonate. Huber and $\mathrm{PRICE}^{2}$ ) also found a similar result using cattle. Fontenot et al. ${ }^{1)}$ found, to the contrary, that the liver iron level was lower for the highest level of dietary calcium than for the two lower levels in sheep.

There was no substantial difference in serum iron concentrations among three rations and these values were similar to the data shown by Koong et al. ${ }^{20)}$ and Hidiroglou and Jenkins ${ }^{21}$. It is well established that serum iron concentrations are decreased in severe cases of iron deficiency ${ }^{3}$. On the other hand, Kawashima stated in his review on trace minerals ${ }^{22}$ that, in general, trace mineral concentrations in blood do not strictly corelated with body stores. In the sheep used in this experiment, iron deficiency might not be so severe as serum iron became lower.

Some studies ${ }^{3,23,24)}$ indicated that the utilization of dietary copper was decreased by the elevation of dietary calcium. In accordance with their observations ${ }^{3,23,24}$, copper retentions decreased as calcium carbonate was added to rations.

In an experiment by HUBER and $\mathrm{PRICE}^{2}$, liver copper stores decreased when dietary calcium was elevated. However, Fontenot et al." found that liver copper in sheep was not affected by increased dietary calcium level. Liver copper concentrations in which there were many variations, fell into a normal range ${ }^{3}$. Furthermore, among three rations, consistent change was not found in liver copper. Liver copper concentrations are useful aids in the diagnosis of copper deficiency ${ }^{25)}$. Therefore, it is conceivable that a severe copper deficiency would not be induced in sheep of this experiment.

Spleen copper concentrations tended to decrease with the increasing of dietary calcium con. tent. The significance of decrease in spleen copper is not obvious, but the copper requirement 


\section{Yano, NoKata and KaWashima}

of ruminant may be elevated as calcium carbonate is added to rations.

Among three rations, no obvious difference was found in the fecal zine concentration arid zinc concentrations of serum, liver and spleen. From the work of OTt et al. ${ }^{26)}$ and Mills et al. ${ }^{2 \pi}$, it appears that phytic acid, in association with high concentrations of calcium in the diet, does not interfere with the utilization of zinc in ruminants. MnLLER ${ }^{28)}$, in his description of zinc metabolism, described this situation as a breakdown of phytic acid in the rumen.

It was indicated by THOMAs $^{8)}$ that high dietary calcium and phosphorus induced the incidence of manganese deficiency in animals. O'DELL's description ${ }^{29)}$ said that high dietary levels of calcium and phosphorus markedly increased the manganese requirement of growing chickens and the phenomenon was best explained by the increase of manganese adsorption on large surface area produced by calcium phosphate complex in the gut. The increase of dietary calcium did not affect manganese balances and liver and spleen manganese concentrations in this experiment. It may be possible that the dietary phosphorus content was not sufficient to form the comlex of calcium, phosphorus and manganese in the gut of sheep.

The results obtained in this experiment suggested that iron and copper requirements would be elevated by the addition of calcium carbonate to rations. But causes as to why calcium carbonate decreases the availability of iron and copper in sheep are not well known. Therefore further studies will be required to clarify these problems.

\section{References}

1) Fontenot, J.P., R. F. Miller and N.O. Price, J. Anim. Sci., 23: 874 (abstract). 1964.

2) Huber, J. T. and N. O. Price, J. Dairy Sci., 54: 429-432. 1971.

3) Underwood, E. J., Trace Elements in Human and Animal Nutrition. 3rd ed, 18-22, 67-78. Academic Press. New York and London. 1971.

4) Heth, D. A., W. H. Becker and W. G. Hoekstra, J. Nutr., 88: 311-316. 1966.

5) Heth, D. A., M. L. Sunde and W. G. Hoekstra, Poultry Sci., 45: 75-83. 1966.

6) Saito, M. and T. Matsumoto, Jap. J. Zootech. Sci., 40: 513-519. 1969.

7) Saito, M. and T. Matsumoto, Jap. J. Zootech. Sei., 41: 9-13. 1970.

8) Thomas, J. W., J. Dairy Sci., 53: 1107-1122. 1970.

9) Fiske, C. H. and Y. Subbarow, J. Biol. Chem., 66: 375-400, 1925.

10) Church, D.C., G. E. Smith, J.P. Fontenot and A. T. Palston, Digestive Physiology and Nutrition of Ruminants. 473-479. O. S. U. Book Stores, Inc., Oregon. USA. 1972.

11) Chapman, H. L. Jr. and M. C. Bell, J. Anim. Sci., 22: 82-85. 1963.

12) Comer, C. L., G. K. Davis and L. Singer, J. Biol. Chem., 174: 905-914. 1948.

13) Kato, K., Ph. D. Thesis. Kyoto University. 1977.

14) Feaster, J.P., S. L. Hansard, J. T. McCall, F. H. Skipper and G. K. Davis, J. Anim. Sci., 13: 781-788. 1954.

15) McCane, R.A. and E.M. Wrddowson, Biochem. J, 36: 692-696. 1942.

16) Milier, W. J., D. M. Blackmon, G. W. Powell, R. P. Gentry and J. M. Hiers, Jr., J. Nutr., 90: 335-341. 1966.

17) Kent, N. L. and R. A. McCane, Biochem. J., 35: 877-883. 1941.

18) Maynard, L.S. and S. Fink, J. Clim. Invest., 35: 831-836. 1956.

19) Watson, L. T., C. B. Ammerman, J. P. Feaster and C. E. Roessler, J. Anim, Sci., 36: 131136. 1973.

20) Koong, L. J., M. B. Wise and E. R. Barrick, J. Anim. Sci., 31: 422-427. 1970. 
21) Hidiroglou, M. and K. J. Jenkins, Can. J. Anim. Sci., 51: 803-806. 1971.

22) Kawashima, R., Jap. J. Zootech. Sci., 44: 497-505. 1973.

23) Kirchgessner, M., World Rev. Anim. Prod., 4: 41-50. 1965.

24) Dick, A. T., Aust. J. Agric. Res., 5: 511-544. 1954.

25) Ammerman, C. B., J. Dairy Sci., 53: 1097-1106. 1970.

26) Oтt, E. A., W. H. Smith, M. Stoв and W.M. Beeson, J. Nutr., 82: 41-50. 1964.

27) Mills, C. F., A.C. Dalgarno, R. B. Williams and J. Quarterman, Brit J. Nutr., 21: 751768. 1967.

28) Miller, W. J., J. Dairy Sci., 53: 1123-1134, 1970.

29) O’Dezl, B. L., Annals N.Y. Acad. Sci., 199: 70-81. 1972.

飼料中への炭酸カルシウム添加がめん羊の鉄, 銅, 严鉛, マンガン代謝に及ぼす影響

矢野秀雄・野方 勝・川島主治

京都大学農学部畜産学科, 京都市 606

平均体重 $42 \mathrm{~kg}$ の9頭のめん羊老 3 頭ずつ 3 区に分 けて，カルシウム含量が $0.1 ， 0.6,1.2 \%$ ある飼料を それぞれ各区のめん羊に給与した。飼料中のカルシウム 水準は炭酸カルシウムの飼料添加により調整した。供試 飼料は濃厚試料を主体とし，粗飼料としては稲わらを用 いた. 試験開始後, 30 日目己60日目から1䓢間, 永,

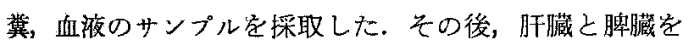
採取するために各区の 3 頭のめ几羊のうち 2 頭を己殺し た，尿中の重金属含量は非常に少なくて，㽷を通しての
排泄は重金属の出納にはほとえど影響を及ぼさないよう であった，血清中の童金属濃度は，各区の間で明らかな 違いは見られなかった。飼料中のカルシウム含量が高く なると蕒中の鉄子銅排泄量は增加 L，体内保有量江低下 した．旰臟中の鉄と銅含量は一定の変化を示さなかった が，脾臓中の鉄と銅含量壮，炭酸カルシウム添加汇より 低下刍る傾向であった，以上の結果より高水準の炭酸力 ルシウムを反すう動物に与えると，鉄と銅の要求量が増 加するものと考えられた。 